\title{
Oral Insulin Increases Small Intestinal Mass and Disaccharidase Activity in the Newborn Miniature Pig
}

\author{
ROBERT J. SHULMAN \\ USDA/ARS Children's Nutrition Research Center. Department of Pediatrics, Baylor College of Medicine and \\ Texas Children's Hospital, Houston, Texas 77030
}

\begin{abstract}
Factors, such as insulin, found in human and pig colostrum and mature milk likely influence small intestinal growth and development. Although pharmacologic doses of insulin injected parenterally may accelerate small intestinal development in altricial animals such as the rodent, the effects of oral insulin on intestinal development have not been studied. In the first of two studies, we randomized 2-d-old miniature piglets to receive bottlefeedings of a swine weaning milk formula with (group $\mathrm{F}+$ I) or without (group F) the addition of insulin. Serum glucose, insulin, and cortisol were measured before and 1 $\mathrm{h}$ after the first feeding the piglets received at our facility. In the second study, piglets were randomized (groups $\mathrm{F}$ and $\mathrm{F}+\mathrm{I}$ ) and fed for $\mathbf{6} \mathrm{d}$, after which blood samples were obtained as in the first experiment. The piglets were then killed and the small intestine removed for analysis. We found no differences between groups in serum glucose, insulin, and cortisol at both 2 and $8 \mathrm{~d}$ of age, both before and after feeding. In the second experiment, small intestinal weight was greater in the $F+I$ than in the $F$ group. Although no differences were noted between groups in the jejunum, values were greater for group F + I versus group $\mathrm{F}$ for ileal mucosal weight, protein, RNA, lactase, and maltase activities. No differences were found between groups in ileal DNA or sucrase activity. We conclude that the administration of oral insulin stimulated an increase in ileal mass and disaccharidase activity in the newborn miniature pig without apparent concomitant changes in serum glucose, insulin, or cortisol. (Pediatr Res 28: 171-175, 1990)
\end{abstract}

The colostrum of a number of species, including the human and the pig, promotes the growth and differentiation of a number of cell types, including those in the small intestine $(1,2)$. Insulin has been suggested as one of the trophic factors present in colostrum $(1,3)$. The concentration of insulin in human and pig colostrum is 3 - to 30 -fold greater than that in serum (4-7). The concentration decreases during the first week postpartum, but appears to remain at or above levels found in serum (4-7). The

Received February 15, 1990; accepted April 11, 1990

Correspondence and reprint requests: Robert J. Shulman, M.D., Children's Nutrition Research Center, 1100 Bates Street, Houston. TX 77030.

This work is a publication of the USDA/ARS Children's Nutrition Research Center, Department of Pediatrics, Baylor College of Medicine and Texas Children's Hospital, Houston. TX. This project has been funded in part with federal funds from the U.S. Department of Agriculture. Agricultural Research Service under Cooperative Agreement number 58-7 MNI-6-100. The contents of this publication do not necessarily reflect the views or policies of the U.S. Department of Agriculture nor does mention of trade names, commercial products, or organizations imply endorsement by the U.S. Government. decrease in the trophic activity of colostrum parallels the decrease in colostral insulin concentration (1).

In previous animal studies of the effect of insulin on small intestinal growth and development, most investigators injected the insulin parenterally $(8-11)$. Although humans and animals receive insulin enterally, e.g. in colostrum, previous investigators have not examined the effect of oral insulin on small intestina growth and development. Our objective was to determine whether oral insulin alters the rate of small intestinal growth (length and mass) and development (disaccharidase activity). We studied the newborn miniature piglet, an animal whose level of gastrointestinal development more closely approximates that of the human newborn than does that of other commonly studied species such as the rat and mouse (12).

\section{MATERIALS AND METHODS}

Design. Hanford miniature piglet littermates (Charles River Breeding Laboratories, Wilmington, MA) were removed from the sow and shipped to our facility at $2 \mathrm{~d}$ of age. Piglets were weighed upon arrival and daily thereafter. Piglet littermates were randomized to receive a swine weaning milk-based formula (Soweena, Merrick's, Union City, WI) either with (group F + I) or without (group F) the addition of $85 \mathrm{mU} / \mathrm{mL}$ of regular porcine insulin (Regular Iletin II, Eli Lilly Co., Indianapolis, IN) In the first experiment, piglets received $20 \mathrm{~mL}$ of formula with or without insulin at the time of their arrival. Blood samples were obtained before and at $60 \mathrm{~min}$ after the first feeding. In the second experiment, the feeding regimen was continued for $6 \mathrm{~d}$. On the 7 th $d$ of study, blood samples were obtained as in the first experiment. The piglets were then killed and the small intestine was removed for analysis.

Feeding. One L of formula was prepared daily for each group (with or without insulin). The respective formula was poured into bottles and nipple-fed at 0800, 1100, 1400, 1700, 2000, and $2400 \mathrm{~h}$. Bottles were weighed before and after feeding and the intake calculated. The piglets were allowed to nurse (i.e. nipple) ad libitum except when the disparity in intakes among animals at each feeding was greater than $10 \%$. In such cases, the piglets were pair-fed to maintain comparable intakes.

Tissue collection. Fentanyl $(0.05 \mathrm{mg} / \mathrm{kg})$ and ketamine (11 $\mathrm{mg} / \mathrm{kg}$ ), administered intramuscularly, were used to anesthetize the piglets. The abdomen was opened and the small intestine, from pylorus to cecum, was removed and placed in cold saline. Length was determined by suspending the small intestine and attaching a $35-\mathrm{g}$ weight. The small intestine was flushed with cold saline and the mesentery was then stripped off. The duodenum was defined as the segment from pylorus to the ligament of Treitz $(12,13)$. The remaining small intestine was divided in half (i.e. jejunum and ileum) $(12,13)$. Each segment was weighed. Because of the large length of small intestine, the jejunum and ileum were divided into six equal segments ( 1 to 6 , proximal to 
distal). Jejunal segment 1 and ileal segment 3 were opened lengthwise and gently blotted. The mucosa was scraped off, and the mucosa and serosa were placed in preweighed tubes and frozen in liquid nitrogen.

Analyses. The blood samples were analyzed for serum glucose using an autoanalyzer (Cobas, Roche Diagnostic, Montclair, NJ) and for insulin and cortisol using a double-antibody RIA (Radioassay Systems Laboratories, Carson, CA). The mucosa was homogenized in deionized water and analyzed for protein by the method of Smith et al. (14). DNA was measured using the technique of Labarca and Paigen (15). RNA was determined using the modified Schmidt-Tannhauser procedure (16). Lactase, sucrase, and maltase activities were measured as previously described $(12,13)$.

Statistics. In the first experiment, 10 piglets (five litters of two littermates) were studied. In the second experiment, 24 piglets (six litters of four littermates each) were studied. Consequently, two-way analysis of variance was used with treatment group as one factor and litter as the other. Changes within individual animals were assessed using a paired $t$ test. Data are expressed as mean $\pm \mathrm{SE}$.

\section{RESULTS}

In the first experiment, pre- and postprandial serum glucose values were similar between groups (Table 1). Serum glucose increased in both groups postprandially. Serum insulin values also were similar between groups before and after the feeding. Serum insulin increased significantly after the feeding only in group F. No differences were noted between groups in pre- and postprandial serum cortisol values. Similar findings were observed in the second experiment on d 6 (data not shown).

In the second experiment, there were no differences between groups in mean initial weight, final weight, weight gain, or formula intake (Table 2). Small intestinal length was similar in both groups $(446 \pm 23$ versus $425 \pm 17 \mathrm{~cm} / \mathrm{kg} ; \mathrm{F}+$ I versus $\mathrm{F}$, respectively). In contrast, small intestinal weight was greater in group $\mathrm{F}+\mathrm{I}$ than in group $\mathrm{F}(41.1 \pm 1.5$ versus $37.0 \pm 1.9 \mathrm{~g} / \mathrm{kg}$, $p<0.001)$. The difference in small intestinal weight resulted from increased ileal mucosal weight in group F + I compared with group $\mathrm{F}$ (Fig. 1). Serosal weight was similar between groups (data not shown). No differences were seen between groups in jejunal mucosal (Fig. 1) or serosal weights (data not shown).

No differences were seen between groups in total jejunal segment protein (Fig. 1). Similar findings were seen for total jejunal segment DNA concentration. Protein/DNA ratio was

Table 1. Results of blood measurements*

\begin{tabular}{ccc}
\hline Measurement & Formula + insulin & Formula \\
\hline Serum glucose $(\mathrm{mmol} / \mathrm{L})$ & & \\
$\quad$ Preprandial & $4.2 \pm 0.4$ & $4.3 \pm 0.5$ \\
$\quad$ Postprandial & $10.6 \pm 1.6$ & $9.4 \pm 0.7$ \\
Serum insulin $(\mathrm{pmol} / \mathrm{L})$ & & \\
$\quad$ Preprandial & $44 \pm 7$ & $72 \pm 22$ \\
$\quad$ Postprandial & $213 \pm 90$ & $163 \pm 39$ \\
Serum cortisol $(\mathrm{nmol} / \mathrm{L})$ & & \\
$\quad$ Preprandial & $331 \pm 119$ & $270 \pm 94$ \\
$\quad$ Postprandial & $331 \pm 124$ & $389 \pm 102$ \\
\hline
\end{tabular}

*Values are means \pm SE. There were no differences between groups.

Table 2. Piglet wt, wt gain, and formula intake*

\begin{tabular}{lcc}
\hline \multicolumn{1}{c}{ Parameter } & Formula + insulin & Formula \\
\hline Initial wt $(\mathrm{g})$ & $793.0 \pm 53$ & $754.0 \pm 43$ \\
Final wt $(\mathrm{g})$ & $1024.0 \pm 62$ & $968.0 \pm 52$ \\
Wt gain $(\mathrm{g} / \mathrm{kg} / \mathrm{d})$ & $44.6 \pm 4.4$ & $43.2 \pm 3.7$ \\
Formula intake $(\mathrm{mL} / \mathrm{kg} / \mathrm{d})$ & $215.2 \pm 6.5$ & $222.1 \pm 7.5$ \\
\hline
\end{tabular}

$*$ Values are means $\pm \mathrm{SE}$. similar between groups in the jejunum. Total jejunal segment RNA was not different between groups.

Because of the increase in ileal mucosal weight, total ileal mucosal segment protein was greater in group $\mathrm{F}+\mathrm{I}$ than in group F (Fig. 1). Total ileal segment DNA was similar between groups. The ileal protein/DNA ratio was greater in group $\mathrm{F}+\mathrm{I}$ than in group F. Total ileal segment RNA was greater in group $\mathrm{F}+\mathrm{I}$ that in group $\mathrm{F}$.

Although jejunal disaccharidase activity was similar between groups, ileal lactase and maltase activities (per kg body wt) were greater in group $\mathrm{F}+\mathrm{I}$ than in group $\mathrm{F}$ (Fig. 2). When expressed per mg protein (Fig. 3), only ileal lactase activity was significantly greater in group $\mathrm{F}+\mathrm{I}$ than in group $\mathrm{F}$. No differences in ileal sucrase activity were noted between groups (Figs. 2 and 3 ).

\section{DISCUSSION}

Our study has demonstrated that ileal mass and lactase activity were increased in newborn miniature pigs in response to orally administered insulin. The increase was sufficiently large that total small intestinal mass was greater in group $\mathrm{F}+\mathrm{I}$ than in group F. Previous in vivo studies have suggested that insulin administered parenterally to 8-d-old mice can stimulate the rate of enterocyte proliferation and cause a precocious increase in sucrase and maltase activities $(10,11,17)$. Other studies in rats have contradicted aspects of the findings in mice $(8,9)$. In vitro studies of the effect of insulin on the small intestine have also produced conflicting results $(3,18-21)$. Contradictions among studies may be explained, in part, by differences in animal species, the ages of the animals studied, and the various dosages of insulin used. The interpretation of studies in which insulin was administered parenterally is difficult, because the animals often developed hypoglycemia (11). Hypoglycemia and its associated stress can stimulate ornithine decarboxylase activity, an enzyme intimately involved in small intestinal growth and development (22). We found no evidence in our study that orally administered insulin affected either serum glucose, insulin, or cortisol (Table 1). The 1-h blood sample should have detected significant changes in either serum glucose or insulin; the maximum increase in these parameters is found at $1 \mathrm{~h}$ during a glucose tolerance test (23).

In our attempt to interpret the effects of insulin on small intestinal growth and development in other animal studies, we found an additional confounding variable, i.e. animal food intake was not controlled $(8,9,10,11,17)$. Insulin stimulates food intake, which in turn can increase small intestinal mass and disaccharidase activity $(24,25)$. By strictly controlling food intake in our study, we avoided this pitfall.

Studies in rats made diabetic suggest that the absence of insulin is associated with an increase in small intestinal mass and disaccharidase activity (26). The hyperphagia associated with diabetes in the rat, however, appears capable of inducing mucosal hypertrophy (24). In addition, diabetes appears to be a poor model in which to study the effects of insulin on the small intestine because the response may differ according to the etiology of the diabetic lesion (e.g. disaccharidase activity increased or unchanged) (26).

In a previous study, we administered different combinations of nutrients (glucose versus a combination of glucose and fat) i.v. to alter serum insulin levels in healthy newborn piglets (13). Although the piglets received no oral intake, they grew normally (13). We found no differences in small intestinal growth and development despite marked differences in serum insulin levels between groups. These data suggest that alterations in serum insulin in the absence of hypoglycemia and changes in food intake do not alter small intestinal growth and development. We thus chose to focus our attention on the possible effect of insulin administered orally with the feeding.

Studies of the effects of insulin administered orally may not have been undertaken previously because insulin administered in this manner is assumed to be degraded rapidly (27). Neverthe- 

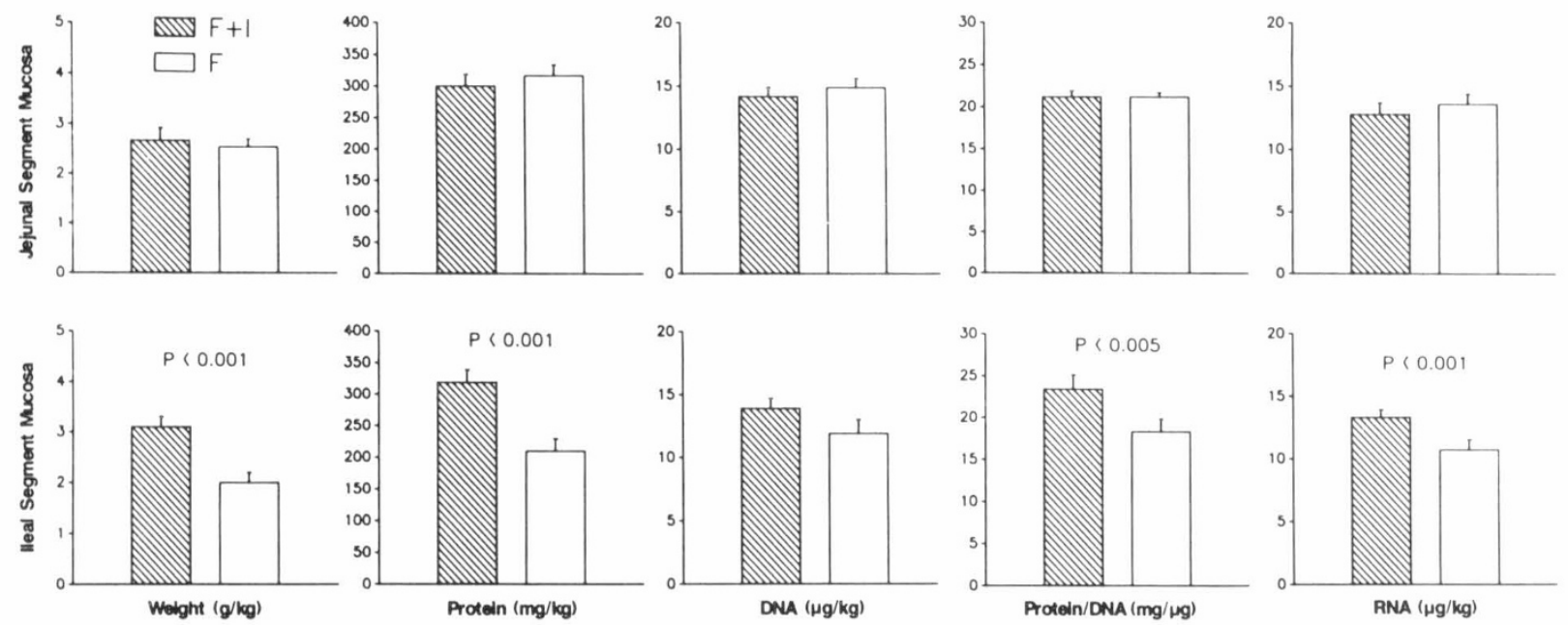

Fig. 1. Hatched hars, formula and insulin; open bars, formula. Upper panel, jejunal segment measurements; Lower panel, ileal segment measurements. Values are means $\pm \mathrm{SE}$.
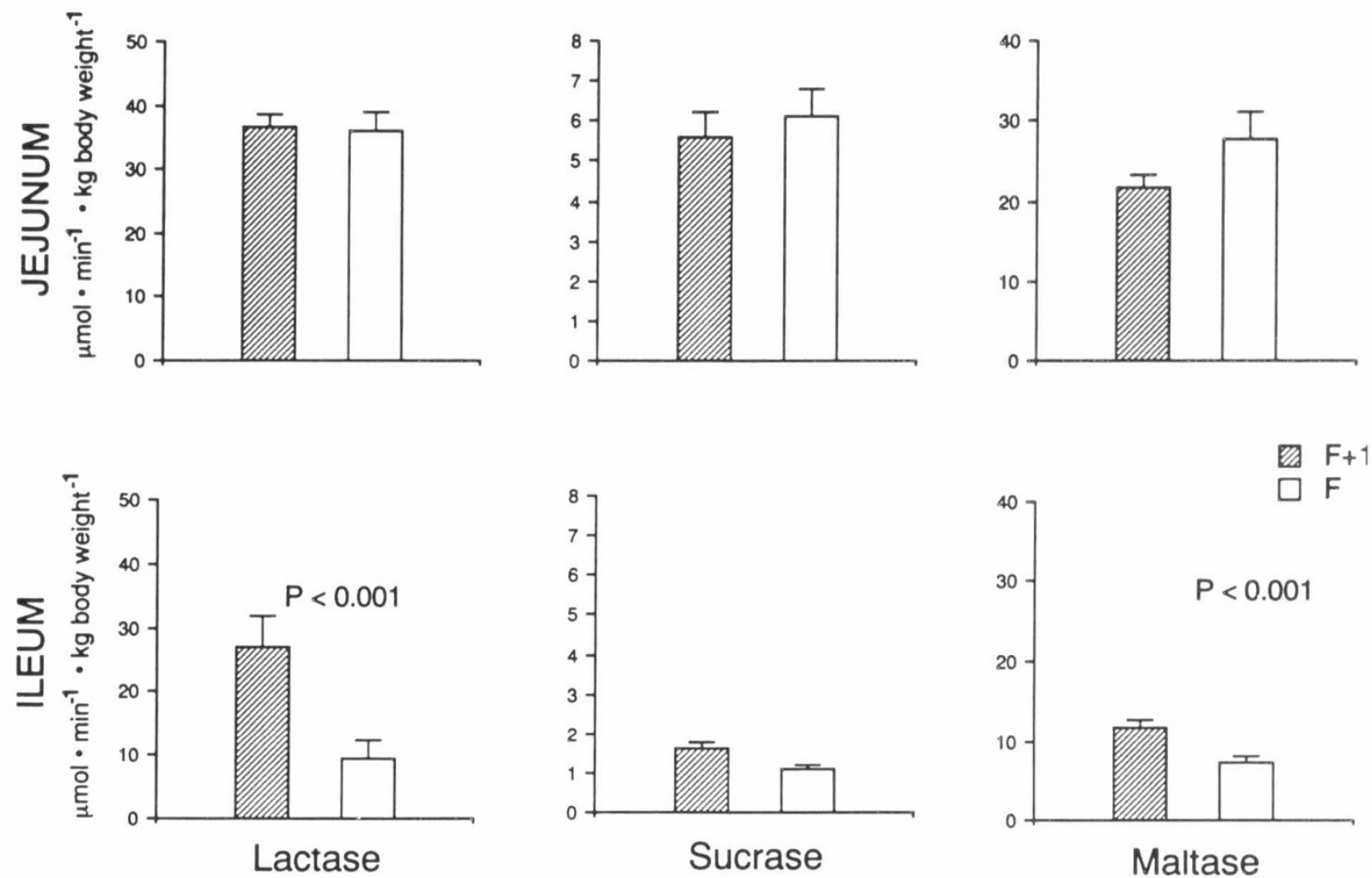

Fig. 2. Hatched hars, formula and insulin; open bars, formula. Upper panel, jejunal disaccharidase measurements expressed per kg body wt: Lower panel, ileal disaccharidase measurements expressed per kg body wt. Values are means \pm SE.

less, pharmacologic doses of oral insulin (more than 170-fold higher than those used in our study) administered to piglets and human infants less than 24-h-old decreased serum glucose, presumably by having been absorbed $(28,29)$. This response does not occur in older animals (rats), even at pharmacologic doses (30). Such studies indicate that after the immediate newborn period, oral insulin does not induce systemic effects (i.e. decrease serum glucose). These data were substantiated in our present study, in which oral insulin did not affect serum glucose, insulin, or cortisol. The possibility remains, however, that small amounts of insulin might escape degradation and affect small intestinal mass and development. Further studies are warranted to test this hypothesis.

The hypothesis that oral insulin may affect small intestinal development and/or function is strengthened by the finding of insulin receptors on the jejunal and ileal brush border surfaces of rat small intestine $(31,32)$. In the dog, however, insulin receptors appear to be much more numerous on the basolateral surface of jejunal enterocytes (33). In the rat, there appear to be no differences between jejunum and ileum in the specific binding of insulin to the receptors (32). Thus, we have yet to determine whether the insulin effects in our study occurred via these receptors.

If we assume that oral insulin did reach the small intestine intact, its effects might conceivably have been found in the jejunum. The effects of insulin added to the food, however, were observed in the ileum, but not the jejunum (Figs. 1-3). In the normal small intestine, jejunal villi are longer than ileal villi. This jejuno-ileal gradient appears to be intrinsically programmed (34). Thus, jejunal mass and enzyme activity may be maximally stimulated in the normal jejunum (34). An increase in the amount of nutrients and chyme within the lumen of the ileum, however, can increase ileal mass (35). Insulin may have altered motility in the jejunum so that a larger portion of the feed 

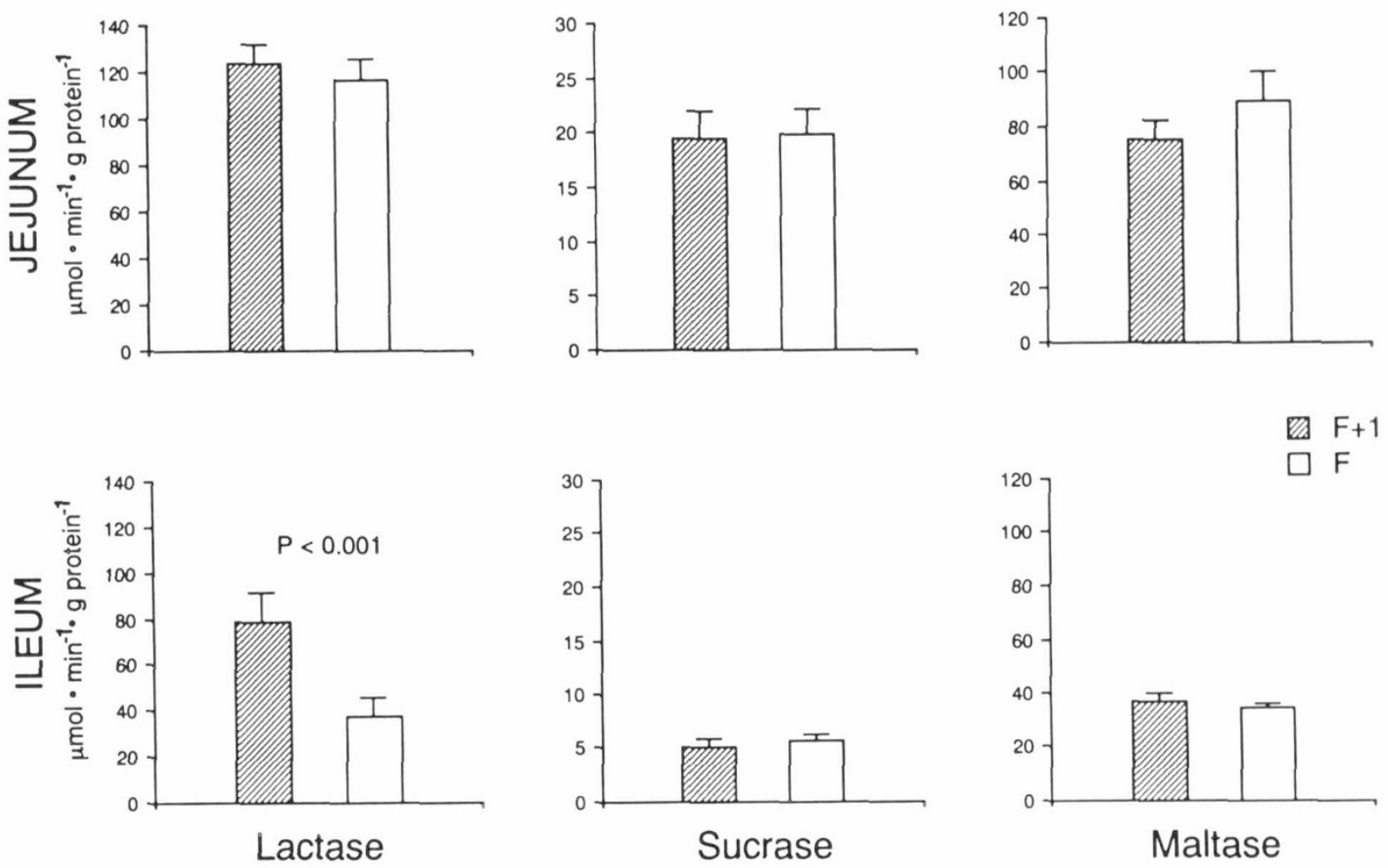

Fig. 3. Hatched hars, formula and insulin; open bars, formula. Upper panel, jejunal disaccharidase measurements expressed per g protein; Lower panel, ileal disaccharidase measurements expressed per g protein. Values are means $\pm \mathrm{SE}$.

reached the ileum and induced mucosal hypertrophy. This would not explain the increase in ileal lactase activity (Figs. 2 and 3), which cannot be induced in the pig (and human) by changes in diet $(36,37)$. Alternatively, insulin may have elicited the release of factor(s), the effects of which are targeted to the ileum. In this regard, it is significant that the insulin treatment did not affect serum cortisol (Table 1), a hormone intimately involved in small intestinal development.

The mechanism by which insulin affects the ileum remains elusive. The increase in ileal mass cannot be explained by differences in tissue hydration, because the protein and RNA concentrations were not different between the two groups of piglets. Insulin may increase enterocyte life-span, perhaps by decreasing the rate of crypt cell production and the rate of cell loss. Tsuboi et al. (38) have suggested that the longer the life-span of the enterocyte, the greater the amount of lactase accreted by the cell. These data support the hypothesis that insulin prolongs enterocyte life-span, which accounts for the greater lactase activity (per g protein) seen in the $\mathrm{F}+\mathrm{I}$ group compared with that in the $\mathrm{F}$ group (Fig. 3). Alternatively, insulin may alter the rate of protein synthesis and/or breakdown (39). The altered rate of protein turnover would be consistent with the effect insulin has on other tissues (39). The larger ileal protein/DNA ratio and higher total segment RNA in group $\mathrm{F}+\mathrm{I}$ compared with that in group $\mathrm{F}$ (Fig. 1) support the latter speculation (40). The speculations, however, are not mutually exclusive; the similar concentrations and total amount per segment of DNA in the groups (Fig. 1) suggest that insulin did not increase cell number. Therefore, the change in ileal mass appears to be the result of hypertrophy rather than hyperplasia.

In summary, we have found that oral insulin administered to the newborn miniature piglet significantly increases small intestinal mass, ileal RNA, and lactase and maltase activities. These changes were unaccompanied by alterations in serum glucose, insulin, or cortisol. In future studies, it will be important to determine whether the amount of insulin that occurs naturally in colostrum is capable of producing the effects observed in our study. The amount of insulin we added to the formula $(85 \mathrm{mU} /$
$\mathrm{mL}$ ), although at least 150 -fold less than that used in previous studies in which insulin was given parenterally, was greater than that found in pig colostrum $(0.85 \mathrm{mU} / \mathrm{mL})(6)$. Because of the important physiologic functions specific to the ileum (e.g. $\mathrm{B}_{12}$ absorption), the dramatic increase in ileal mass and enzyme activities induced by insulin suggests a possible clinical application in patients whose intestinal function is limited, for example, premature infants.

Acknowledgments. The authors thank J. S. Perkinson, M.T.(ASCP), C. Imo, C. Davis, and D. Burrin, Ph.D., for expert technical assistance; S. J. Henning, Ph.D., M. L. Fiorotto, Ph.D., L. R. Johnson, Ph.D., and D. R. Tivey, Ph.D. for valuable comments and suggestions; E. R. Klein for editorial review; and C. Fedrick for preparation of the manuscript.

\section{REFERENCES}

1. Read LC, Upton FM, Francis GL, Wallace JC, Dahlenberg GW. Ballard FJ 1984 Changes in the growth-promoting activity of human milk during lactation. Pediatr Res 18:133-139

2. Cera K, Mahan DC, Simmen FA 1987 In vitro growth promoting activity of porcine mammary secretions: initial characterization and relationship to known peptide growth factors. J Anim Sci 65:1149-1159

3. Baliga BS, Borowitz SM 1988 Effects of growth and differentiation inducing factors on protein kinase-C of cultured intestinal crypt cells. Biochem Biophys Res Comm 154:278-284

4. Kulski JK, Hartmann PE 1983 Milk insulin. GH and TSH: relationship to changes in milk lactose, glucose and protein during lactogenesis in women. Endocrinol Exp 17:317-326

5. Slebodzinski AB, Nowak J, Gawecka H, Sechman A 1986 Thyroid hormones and insulin in milk; a comparative study. Endocrinol Exp (Bratisl) 20:247254

6. Weström BR, Ekman R, Svendsen L, Svendsen J, Karlsson BW 1987 Levels of immunoreactive insulin, neurotensin, and bombesin in porcine colostrum and milk. J Pediatr Gastroenterol Nutr 6:460-465

7. Jaeger A, Lamar CH, Bottoms GD, Cline TR 1987 Growth-stimulating substances in porcine milk. Am J Vet Res 48:151-153

8. Buts J-P, de Keyser N, Dive C 1988 Intestinal development in the suckling rat: effect of insulin on the maturation of villus and crypt cell functions. Eur $\mathrm{J}$ Clin Invest 18:391-398

9. Lee PC, Brooks S, Lebenthal E 1983 Effect of glucose and insulin on small intestinal brush border enzymes in fasted rats. Soc Exp Biol Med 173:372378 
10. Menard D. Malo C 1979 Insulin-evoked precocious appearance of intestinal sucrase activity in suckling mice. Dev Biol 69:661-665

11. Menard D, Malo C. Calvert R 1981 Insulin accelerates the development of intestinal brush border hydrolases in suckling mice. Dev Biol 85:100-105

12. Shulman RJ, Henning SJ, Nichols BL 1988 The miniature pig as an animal model for the study of intestinal enzyme development. Pediatr Res 23:311315

13. Shulman RJ 1988 Effect of different total parenteral nutrition fuel mixes on small intestinal growth and differentiation in the infant miniature pig. Gastroenterology 95:85-92

14. Smith PK, Krohn RI, Hermanson GT. Mallia AK, Gartner FH. Provenzano MD, Fujimoto EK, Goeke NM, Olson BJ, Klenk DC 1985 Measurement of protein using bicinchoninic acid. Anal Biochem 150:76-85

15. Labarca C, Paigen K 1980 A simple, rapid, and sensitive DNA assay procedure Anal Biochem 102:344-352

16. Munro HN. Fleck A 1966 Recent developments in the measurement of nucleic acids in biologic materials. Analyst 91:78-88

17. Malo C, Menard D 1983 Synergistic effects of insulin and thyroxine on the differentiation and proliferation of epithelial cells of suckling mouse small intestine. Biol Neonate 44:177-184

18. Arsenault P. Menard D 1984 Insulin influences the maturation and proliferation of suckling mouse intestinal mucosa in serum-free organ culture. Biol Neonate 46:229-236

19. Beaulieu J-F, Calvert R 1986 Role of thyroxine and insulin on the development of the fetal mouse duodenum in organ culture. Can J Physiol Pharmacol 64:1137-1142

20. Moog F, Goellner JJ 1982 Chick embryo intestine in culture: influence of insulin and other hormones on sucrase, maltase, and alkaline phosphatase. J Pediatr Gastroenterol Nutr 1:401-410

21. Simon PM. Kedinger M. Raul F. Grenier JF. Haffen K 1982 Organ culture of suckling rat intestine: comparative study of various hormones on brush border enzymes. In Vitro Cell Dev Biol 18(4):339-346

22. Baer AR. Cheeseman CI. Thomson ABR 1987 Substrate specificity in the stimulation of intestinal ornithine decarboxylase activity by refeeding after starvation. Biochim Biophys Acta 924:257-259

23. Hedding LG, Rasmussen SM 1972 Determination of pancreatic and gut glucagon-like immunoreactivity (GLI) in normal and diabetic subjects. Diabetologia 8:408-411

24. Jervis EL, Levin RJ 1966 Anatomic adaptation of the alimentary tract of the rat to the hyperphagia of chronic alloxan-diabetes. Nature 210:391-392
25. Larner J, Haynes RC 1975 Insulin and oral hypoglycemic drugs, glucagon. In: Goodman LS, Gilman A (eds) The Pharmacologic Basis of Therapeutics. Macmillan Publishing Co, New York, p 1518

26. Wen D, Henning SJ, Hazelwood RL 1988 Effects of diabetes on development of small intestinal enzymes of infant rats. Soc Exp Biol Med 187:51-57

27. Crane CW, Luntz GRWN 1968 Absorption of insulin from the human small intestine. Diabetes 17:625-627

28. Asplund JM, Grummer RH, Phillips PH 1962 Absorption of colostral gammaglobulins and insulin by the newborn pig. J Anim Sci 21:412-413

29. Znamenacek K, Pribylova H 1963 Vliv aplikace glukozy a insulinu na glykemicke krivky novorozence. Cesk Pediatr 2:104-109

30. Mosinger B, Placer Z, Koldovsky O 1959 Passage of insulin through the wall of the gastrointestinal tract of the infant rat. Nature 184:1245-1246

31. Forgue-Lafitte ME, Marescot MR, Chamblier MC, Rosselin G 1980 Evidence for the presence of insulin binding sites in isolated rat intestinal epithelial cells. Diabetologia 19:373-378

32. Fernandez-Moreno MD, Serrano-Rios M. Prieto JC 1987 Identification of insulin receptors in epithelial cells from duodenum, jejunum, ileum, caecum, colon, and rectum in the rat. Diabete Metab 13:135-139

33. Gingerich RL, Gilbert WR. Comens PG, Gavin JR 1987 Identification and characterization of insulin receptors in basolateral membranes of dog intestinal mucosa. Diabetes 36:1124-1129

34. Koldovsky O 1983 Longitudinal specialization of the small intestine: developmental aspects. Gastroenterology 85:1436-1437

35. Altmann GG, Leblond CG 1970 Factors influencing villus size in the small intestine of adult rats as revealed by transposition of intestinal segments. Am J Anat 127:15-36

36. Flores CA, Brannon PM, Bustamente SA, Bezerra J, Butler KT, Goda T, Koldovsky O 1988 Effect of diet on intestinal and pancreatic activities in the pig. J Pediatr Gastroenterol Nutr 7:914-921

37. Rosensweig NS, Herman RH 1968 Control of jejunal sucrase and maltase activity by dietary sucrose and fructose in man. J Clin Invest 47:2253-2262

38. Tsuboi KK, Kwong LK, Ford WDA, Colby T, Sunshine P 1981 Delayed ontogenic development in the bypassed ileum of the infant rat. Gastroenterology 80:1550-1557

39. Straus DS 1981 Effects of insulin on cellular growth and proliferation. Life Sci 29:2131-2139

40. Koldovsky O, Herbst JJ, Burke J, Sunshine P 1970 RNA and DNA in intestinal mucosa during development of normal and cortisone-treated rats. Growth $34: 359-367$ 